Article

\title{
Evaluation of Melatonin Secretion and Metabolism Exponents in Patients with Ulcerative and Lymphocytic Colitis
}

\author{
Cezary Chojnacki ${ }^{1, *}$, Janusz Błasiak ${ }^{2}$, Jakub Fichna ${ }^{3}{ }^{(0)}$, Jan Chojnacki ${ }^{1}$ \\ and Tomasz Popławski ${ }^{2}$ \\ 1 Department of Clinical Nutrition and Gastroenterological Diagnostics, Medical University, \\ 90-647 Lodz, Poland; jan.chojnacki@umed.lodz.pl \\ 2 Department of Molecular Genetics, University of Lodz, 90-647 Lodz, Poland; \\ janusz.blasiak@biol.uni.lodz.pl (J.B.); tomasz.poplawski@biol.uni.lodz.pl (T.P.) \\ 3 Department of Biochemistry, Medical University of Lodz, 90-647 Lodz, Poland; jakub.fichna@umed.lodz.pl \\ * Correspondence: cezary.chojnacki@umed.lodz.pl; Tel.: +48-42-6393049
}

Received: 3 January 2018; Accepted: 26 January 2018; Published: 29 January 2018

\begin{abstract}
Inflammatory bowel diseases, particularly ulcerative colitis (UC) and lymphocytic colitis (LC), affect many people. The role of melatonin in the pathogenesis of UC is precisely determined, whereas in LC it remains unknown. The aim of this study was to compare the expression of the melatonin-synthesizing enzymes tryptophan hydroxylase (TPH1), arylalkylamine- $N$-acetyltransferase (AANAT), and $N$-acetylserotonin methyltransferase (ASMT) in the colonic mucosa and urinary excretion of 6-sulfatoxymelatonin in patients with ulcerative and lymphocytic colitis. The study included 30 healthy subjects (group C), 30 patients with severe ulcerative colitis (group UC), and 30 patients with lymphocytic colitis (group LC). The diagnosis was based on endoscopic, histological, and laboratory examinations. Biopsy specimens were collected from right, transverse, and left parts of the colon. The levels of mRNA expression, TPH1, AANAT, and ASMT were estimated in the colonic mucosa with RT-PCR. The urine concentration of aMT6s was determined by the photometric method. The expression of TPH1, AANAT, and ASMT in colonic mucosa in UC and LC patients was significantly higher than in healthy subjects. Significant differences were found in the urinary aMT6s excretion: group C $-13.4 \pm 4.8 \mu \mathrm{g} / 24 \mathrm{~h}$, group UC $-7.8 \pm 2.6 \mu \mathrm{g} / 24 \mathrm{~h}(p<0.01)$, group LC $-19.2 \pm 6.1 \mu \mathrm{g} / 24 \mathrm{~h}(p<0.01)$. Moreover, a negative correlation was found between fecal calprotectin and MT6s-in patients with UC $-\mathrm{r}=-0.888$ and with LC $-r=-0.658$. These results indicate that patients with UC and those with LC may display high levels of melatonin-synthesizing enzymes in their colonic mucosa, which could possibly be related to increased melatonin synthesis as an adaptive antioxidant activity.
\end{abstract}

Keywords: melatonin; TPH1; AANAT; ASMT; ulcerative colitis; lymphocytic colitis

\section{Introduction}

Melatonin plays an important role, which is particularly protective, in the gastrointestinal (GI) tract, and the GI tract is its rich source [1-3]. Exogenous L-tryptophan, which may be found in many food products, is a substrate for the synthesis of this indoleamine. L-tryptophan is converted to 5-hydroxytryptamine (serotonin) by tryptophan hydroxylase (TPH1) and 5-hydroxytryptophan decarboxylase (DDC). Serotonin is then converted to $\mathrm{N}$-acetyltryptamine by arylalkylamine- $N$-acetyltransferase (AANAT), and finally $N$-acetylserotonin methyltransferase (ASMT) conditions the conversion of $\mathrm{N}$-acetyltryptamine to $\mathrm{N}$-acetyl-5-methoxytryptamine (melatonin) $[4,5]$. 
The expression of TPH1, AANAT, and ASMT is regulated by the adrenergic system, and may change under the influence of many agents, including neuromodulatory, hormonal, and inflammatory factors [6,7]. In healthy subjects, melatonin is absorbed from the GI tract and transported by the portal vein system to the liver, where it is metabolized mainly to 6-sulfatoxymelatonin (aMT6s) [8,9]. The 6-sulfatoxymelatonin is excreted with urine, and its content in 24-h urine collection is recognized as a good index of pineal and extra-pineal melatonin synthesis [10,11].

An alternative catabolic pathway in the liver includes melatonin oxidation by indoleamine 2,3-dioxygenase and myeloperoxidase to $\mathrm{N}$-acetyl-formylo-5-metoxykynuramine (AFMK) and $\mathrm{N}$-acetyl-5-metoxykykuramine (AMK) [12,13].

Melatonin is also metabolized non-enzymatically by free radicals and other oxidants. After neutralizing two hydroxyl radicals $(\mathrm{OH} \cdot)$, it is converted to cyclic 3-hydroxymalatonin, or it is metabolized to kynuramine derivatives [14,15]. In some extrahepatic tissues, the process is even more intensive, because at low activity of P450 monooxygenase, only a small amount of aMT6s is generated, and AFMK becomes the main product of melatonin oxidation [16]. The extrahepatic melatonin processes and their rates are still poorly recognized. In addition to these, direct interactions of melatonin with reactive oxygen species may increase the activity of antioxidants and antioxidant enzymes such as superoxide dismutase (SOD), glutathione peroxidase (GPx), and glutathione reductase (GSH), and induce the downregulation of pro-oxidant enzymes such as nitric oxide synthase and lipogenase [17-19].

In patients with UC, melatonin synthesis and metabolism depend on many agents, particularly on the nature and severity of the inflammatory process [20].

$\mathrm{UC}$ is a chronic disease with periods of exacerbation and remission. The pathogenesis of UC is complex, involving inflammatory and immune factors, endothelial barrier dysfunction, and the overproduction of reactive oxygen forms, all of which play a role in the destruction of colonic mucosa [21,22]. Inflammatory cells such as neutrophils, lymphocytes $\mathrm{T}$ and $\mathrm{B}$, monocytes macrophages, and mast cells infiltrate tissues in the region of inflammation. The accumulation of immune cells in the colonic tissue and their activation induces an inflammatory response and leads to the local elevation of pro-inflammatory cytokines $[23,24]$. The intensity of infiltration with inflammatory cells and the predominance of selected cells depends on the UC stage. Neutrophils predominant in the period of exacerbation build clusters, which are the so-called crypt abscesses. In this phase of the disease, an increase in the number of enterochromaffin cells (EC) could be observed, which was proven in our previous studies [25] and in the reports of other authors [26,27]. It should be expected that when the number of EC cells increases, there will also be an increase of their products, including melatonin.

Lymphocytic colitis (LC) is a common cause of chronic diarrhea, abdominal discomfort, and other gastrointestinal symptoms [28,29]. Its etiology is unknown-infections, immunologic, hormonal, and other factors are suspected [30-33]. A colonoscopy usually shows normal colonic mucosa, but in microscopic examination, changes are found in biopsies from the right and left part of the colon $[34,35]$. This disease is mainly characterized by intraepithelial lymphocytosis-more than 20 lymphocytes per 100 surface colonocytes [36,37]. Furthermore, a hypertrophy of colonic neuroendocrine cells was observed [38], but their secretion activity was not estimated.

The aim of this study was to compare the expression of melatonin-synthesizing enzymes (TPH1, AANAT, and ASMT) in colonic mucosa and urinary excretion of aMT6s in patients with UC and LC.

\section{Results}

The initial laboratory tests indicate that inflammatory exponents, such as C-reactive protein and fecal calprotectin, were significantly higher in patients with UC compared to those with LC $-p<0.001$ (Table 1). The urinary excretion of 6-sulfatoxymelatonin was lower in UC patients than in those with $\mathrm{LC}-7.86 \pm 2.69 \mu \mathrm{g} / 24 \mathrm{~h}$ vs. $19.2 \pm 6.14 \mu \mathrm{g} / 24 \mathrm{~h}(p<0.001$, Table 1$)$. 
In healthy subjects, TPH1 expression in colonic mucosa was $1.19 \pm 0.41$; in patients with UC, it was $2.71 \pm 0.97(p<0.001)$; and in patients with LC, it was $2.38 \pm 0.64(p<0.001$, Figure 1$)$. No significant difference was observed between the UC and LC group ( $p=0.455)$.

The level of AANAT expression in the control group was $1.32 \pm 0.46$, whereas in the UC group it reached $1.68 \pm 0.54(p<0.01)$, and in the LC group, it was $2.29 \pm 0.69(p<0.001)$. The difference between inflammatory groups was statistically significant $(p<0.01$, Figure 2$)$.

Table 1. General characteristics of subjects included in the study and some initial laboratory results; C-reactive protein (CRP), fecal calprotectin (FC), urinary 6-sulfatoxymelatonin excretion (aMT6 s $_{\mathrm{s}}$.

\begin{tabular}{ccccc}
\hline \multicolumn{2}{c}{ Features } & Control Group $(\boldsymbol{n}=\mathbf{3 0})$ & Ulcerative Colitis $(\boldsymbol{n}=\mathbf{3 0})$ & Lymphocytic Colitis $(\boldsymbol{n}=\mathbf{3 0})$ \\
\hline \multicolumn{2}{c}{ Age-years } & $38.9 \pm 9.4$ & $41.4 \pm 10.2$ & $43.7 \pm 12.4$ \\
\hline \multirow{2}{*}{ Gender } & M & 16 & 13 & 14 \\
& K & 14 & 17 & 16 \\
\hline \multicolumn{2}{c}{ CRP $(\mathrm{mg} / \mathrm{L})$} & $1.97 \pm 1.05$ & $242.9 \pm 99.4$ & $2.58 \pm 1.81$ \\
FC $(\mu / \mathrm{g})$ & $25.8 \pm 9.72$ & $498.6 \pm 338.3$ & $40.8 \pm 21.0$ \\
aMT6 & $(\mu \mathrm{g} / 24 \mathrm{~h})$ & $13.4 \pm 4.87$ & $7.86 \pm 2.69$ & $19.2 \pm 6.14$ \\
\hline
\end{tabular}

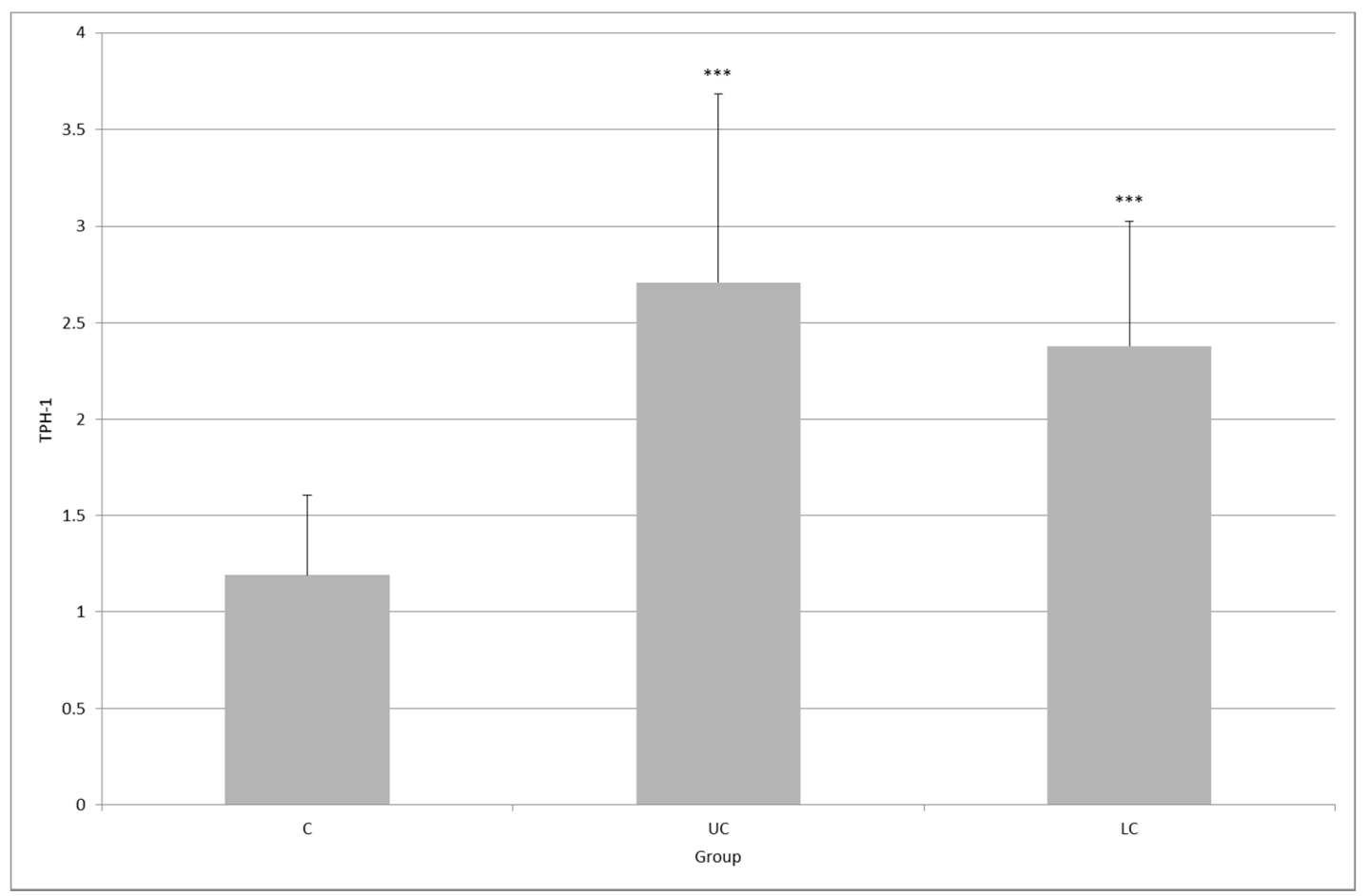

Figure 1. Expression of tryptophan hydroxylase (TPH1) in colonic mucosa in healthy subjects (C) and in patients with ulcerative colitis (UC) and lymphocytic colitis (LC); ${ }^{* * *} p<0.001$, the difference between UC and LC was not statistically significant $(p=0.455)$.

The level of ASMT expression in both UC and LC groups was higher than that in the control group: $1.51 \pm 0.58$ versus $2.03 \pm 1.97(p<0.01)$ and $2.77 \pm 2.61(p<0.001)$. Here, the difference between the UC group and the LC group was statistically significant $(p<0.01$, Figure 3$)$.

A negative correlation was found between the serum level of $C$-reactive protein and urinary aMT6s excretion in the group with UC $(p<0.001$, Figure 4$)$ as well as in the group with LC $(p<0.01$, Figure 5).

Similarly, a negative correlation was indicated between the volume of fecal calprotectin in both groups; $p<0.001$ and $p<0.01$ for UC and LC patients, respectively (Figures 6 and 7). 


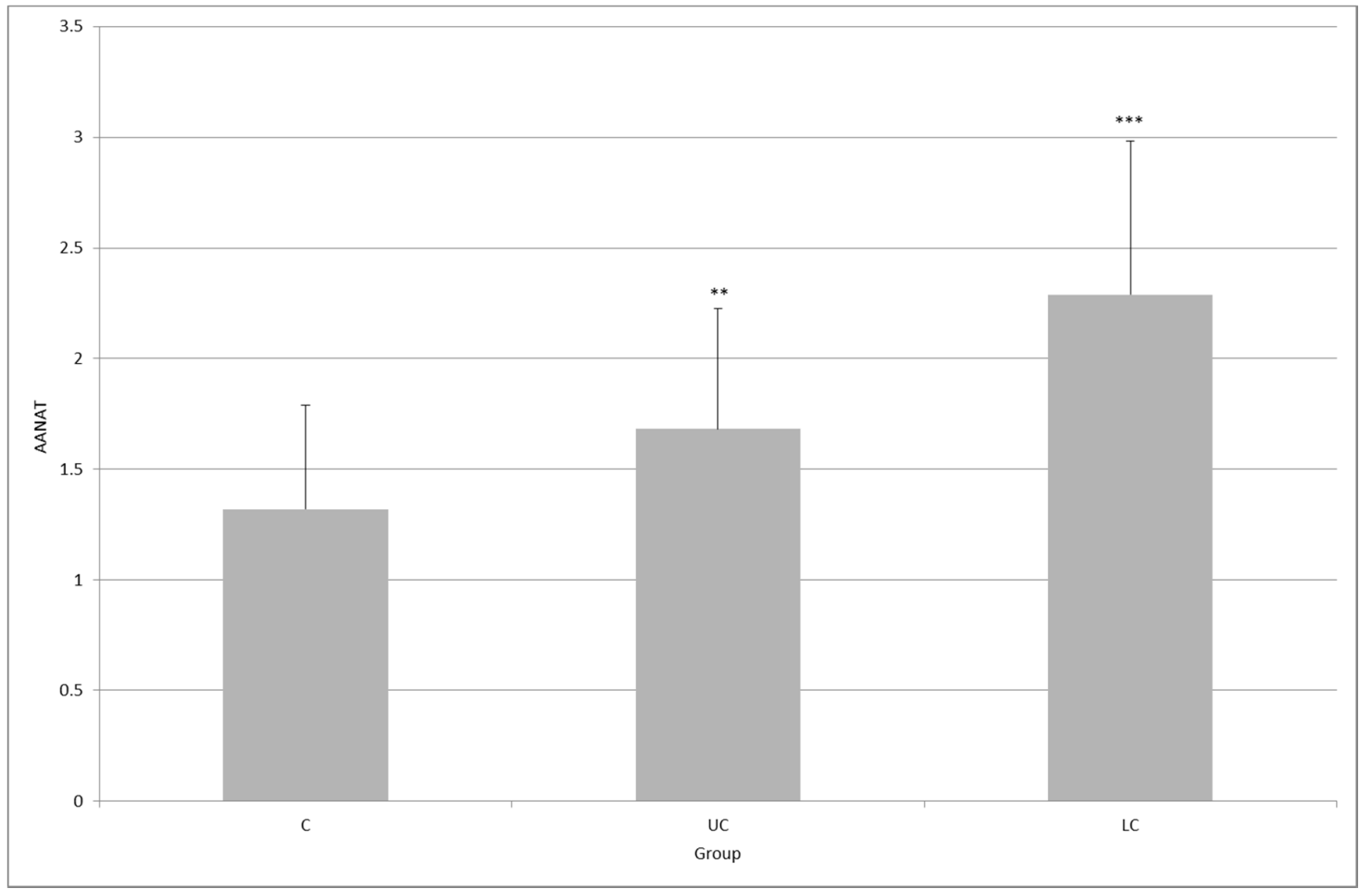

Figure 2. Expression of arylalkylamine- $N$-acetyltransferase (AANAT) in the colonic mucosa of healthy subjects (C), and in patients with ulcerative colitis (UC) and lymphocytic colitis (LC); ${ }^{* *} p<0.01$, *** $p<0.001$; the difference between UC and LC was statistically significant $(p<0.01)$.

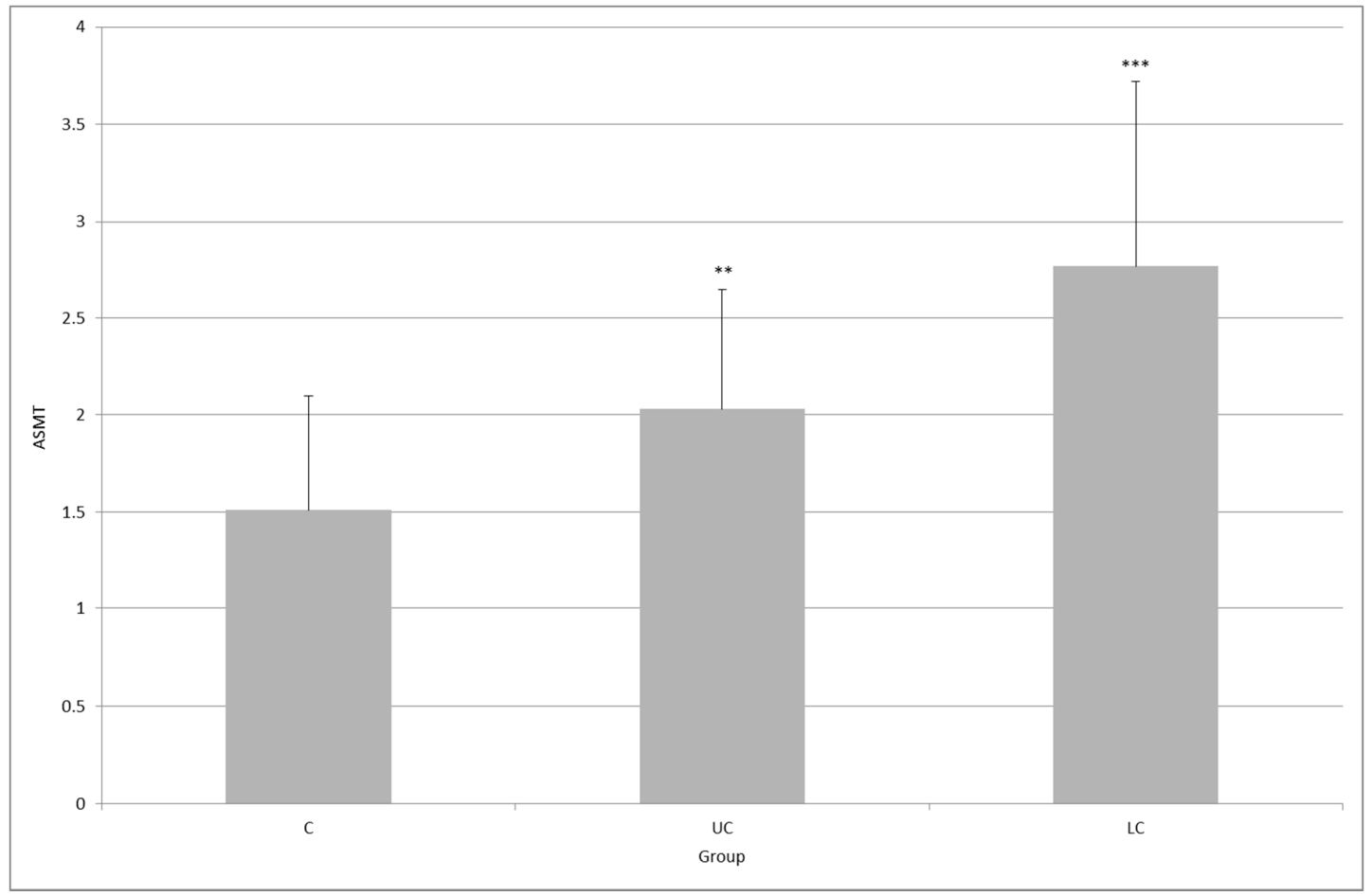

Figure 3. Expression of $N$-acetylserotonin methyltransferase (ASMT) in the colonic mucosa of healthy subjects (C), and in patients with ulcerative colitis (UC) and lymphocytic colitis (LC); ${ }^{* *} p<0.01$, ${ }^{* * *} p<0.001$; the difference between UC and LC groups was statistically significant $(p<0.01)$. 


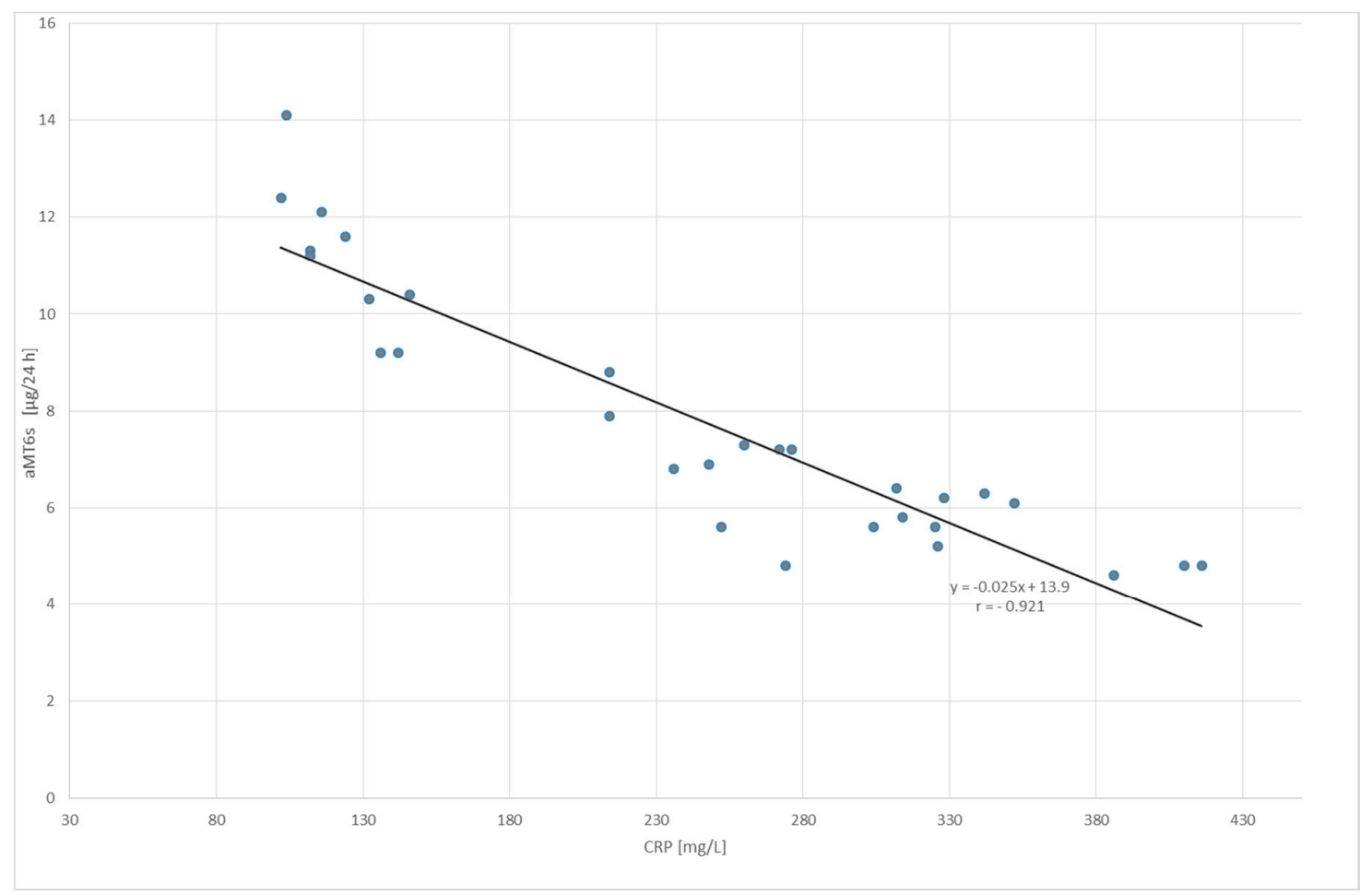

Figure 4. Correlation between the serum level of C-reactive protein (CRP) and urinary 6-sulfatoxymelatonin ( $\left(\mathrm{aMT}_{\mathrm{s}}\right.$ ) excretion in patients with ulcerative colitis; $p<0.001$.

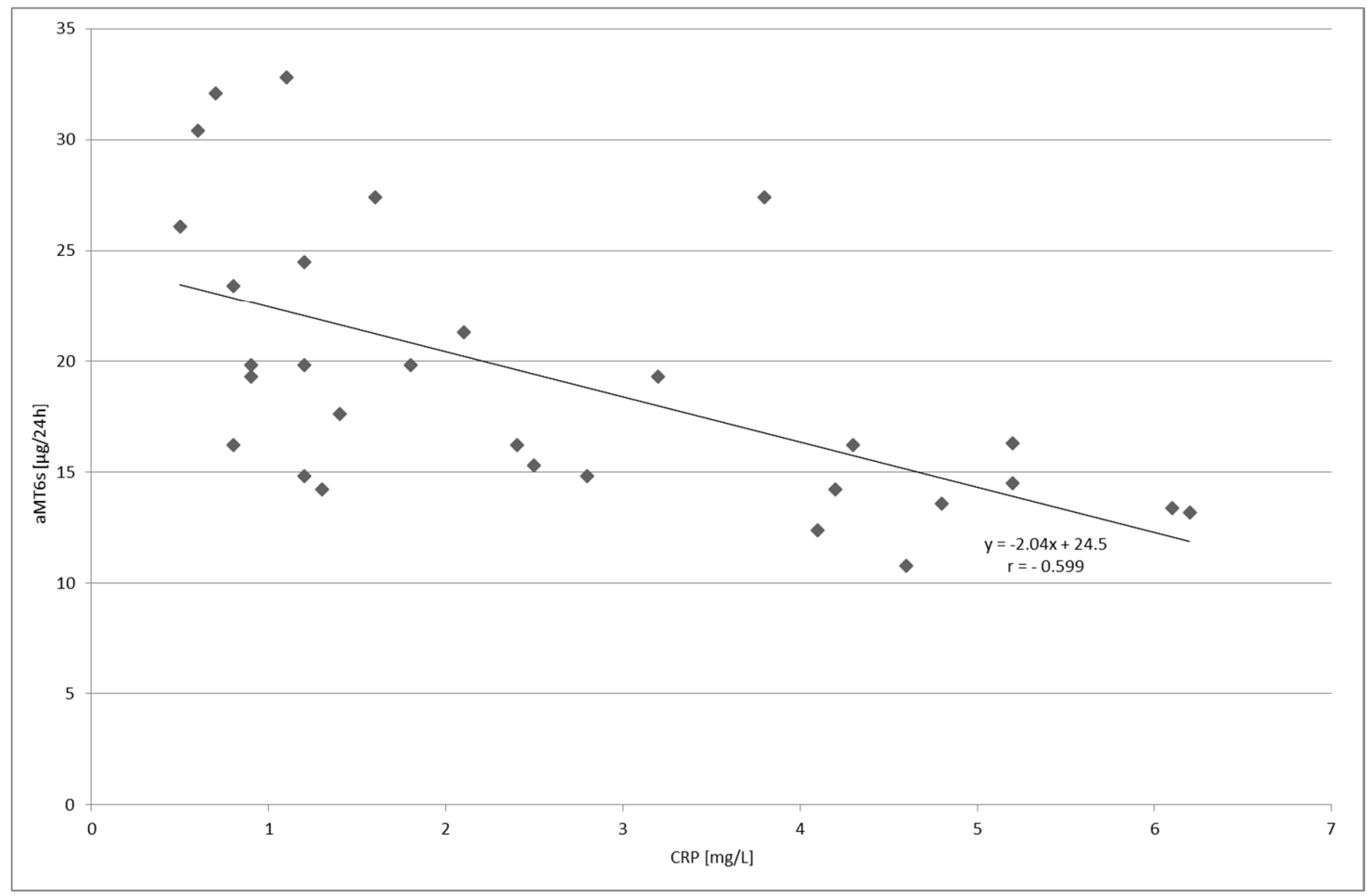

Figure 5. Correlation between the serum level of C-reactive protein (CRP) and urinary 6-sulfatoymelatonin (aMT6s) excretion in patients with lymphocytic colitis, $p<0.001$. 


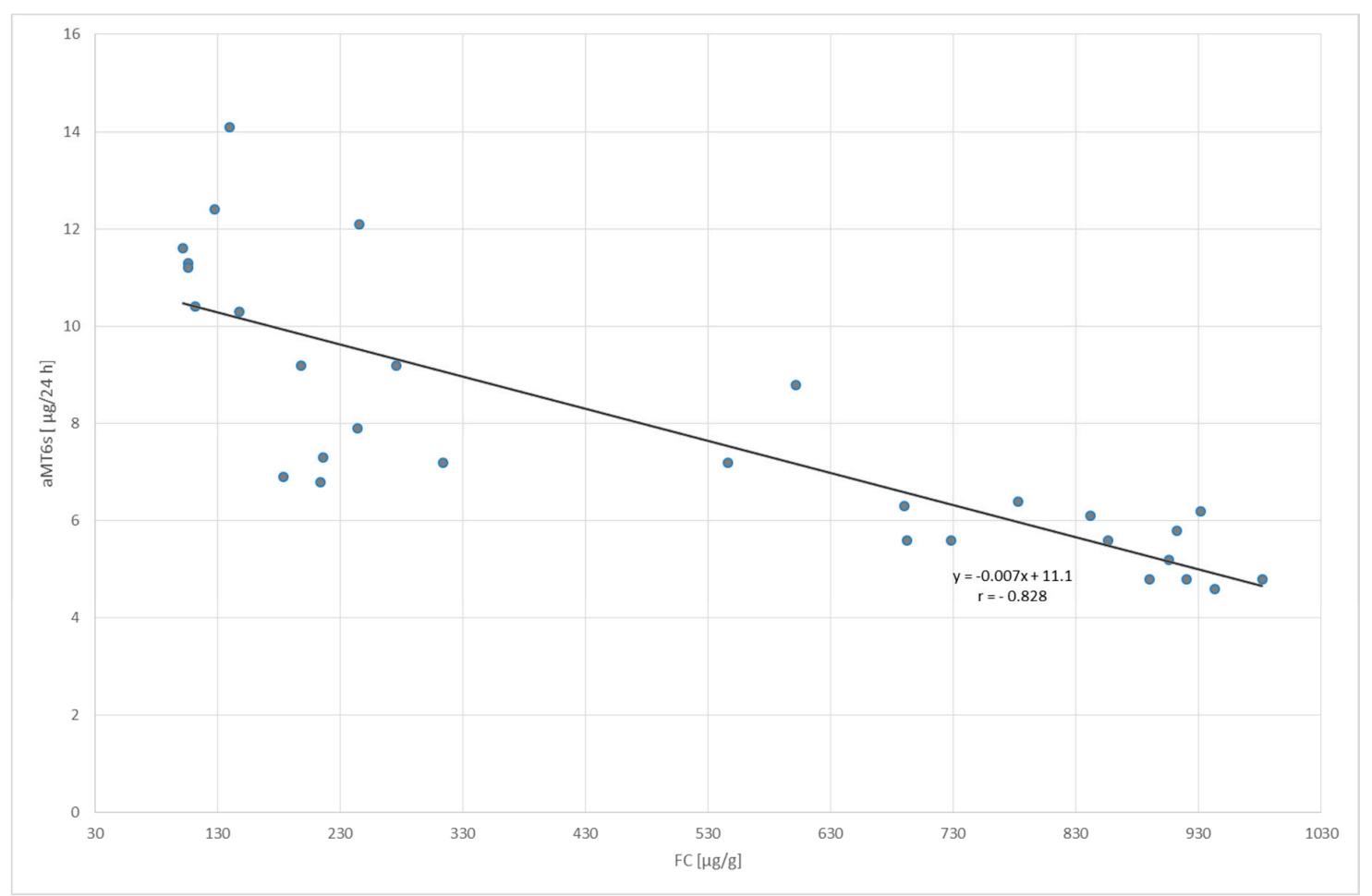

Figure 6. Correlation between fecal calprotectin (FC) concentration and urinary 6-sulfatoxymelatonin (aMT6s) excretion in patients with ulcerative colitis; $p<0.001$.

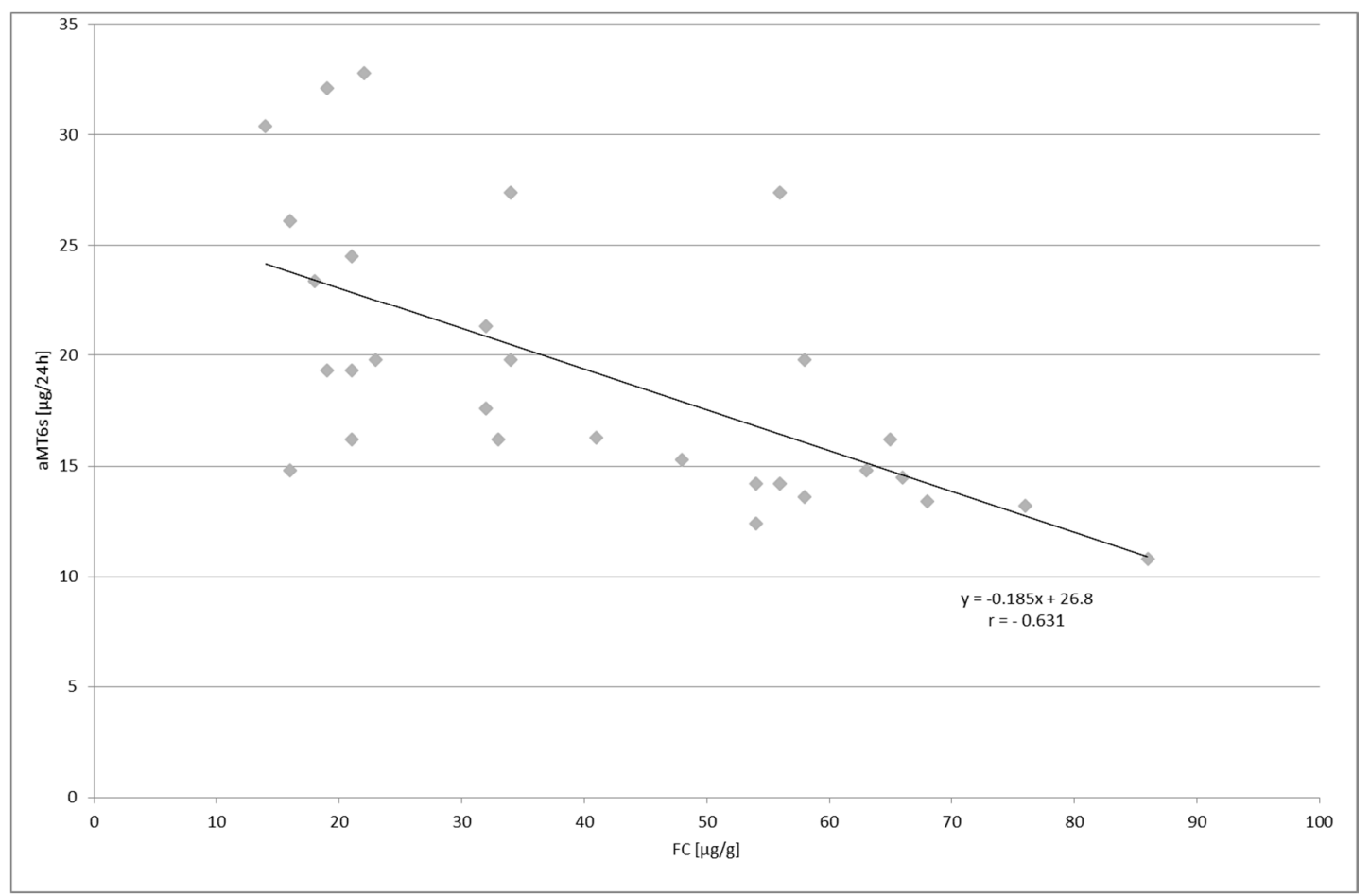

Figure 7. Correlation between fecal calprotectin (FC) concentration and urinary 6-sulfatoxymelatonin (aMT6s) excretion in patients with lymphocytic colitis; $p<0.01$. 


\section{Discussion}

The obtained results confirm our earlier observations, and indicate that the expression of TPH1 and HIOMT (hydroxyindole-O-methyltransferase) in colonic mucosa is significantly higher in UC patients than in healthy subjects [25]. Therefore, it should be acknowledged that inflammatory processes in the colon are accompanied by an increased secretion of enteral melatonin. However, decreased plasma levels of melatonin and urine excretion of aMT6s were observed in patients with ulcerative colitis $[39,40]$. This may result from the fact that the synthesis and catabolism of melatonin, both in the colon and in the liver, can be modified by many factors, including pro-inflammatory cytokines. Furthermore, melatonin is also metabolized non-enzymatically due to its "consumption" in the reaction with oxygen free radicals at the infection sites.

A particularly important outcome of the study is that now it can be presumed that the level of urinary aMT6s excretion can serve as a biomarker and activity index of colon inflammation in patients with UC, along with C-reactive protein and fecal calprotectin. This may have a tremendous implication for the further diagnosis and treatment efficacy of UC patients.

Unlike in UC, the activity index of LC is poorly determined, and is mainly related to clinical symptoms [41-43]. In this disease, the results of the laboratory tests are usually normal or disclose unspecific abnormalities. Patients with LC also have a normal endoscopic appearance, with an occasional erythema and/or patchy edema distributed along the colon $[44,45]$. The histological picture is a significant lymphocytic infiltration in the surface epithelium, but there are also plasma cells, eosinophils, mast cells, macrophages, and neutrophils with a normal architecture of the crypt [46,47]. Enterochromaffin cells are also present at sites of inflammation. Several potential markers for the diagnosis of LC do exist, but their productive capacity still needs confirmation and measurement in a clinical setting [48]. A markedly higher density of chromogranin A-cells was shown to be present in LC colonic mucosa [49]. Another study not only confirmed these results, but also demonstrated that the significant increase of $\mathrm{CgA}+$ cells in lymphocytic colitis is present both in the right and left colon [50]. The authors suspected that if confirmed, this finding might permit the distinction between the diagnosis of LC and IBS by collecting biopsies during simple sigmoidoscopy. It should be expected that an increase in the number of enterochromaffin cells in colonic mucosa would be also found in patients with UC [26,27] and IBS (Irritable Bowel Syndrome) [51,52], and melatonin can be synthesized in other inflammatory cells, particularly in human lymphoid cells [53].

Our study indicates that melatonin-synthesizing enzymes and urine aMT6s excretion were higher in patients with LC than in healthy subjects, which confirms their diagnostic potential. Undisturbed melatonin synthesis arguably protects against the destruction of colonic mucosa due to its antioxidant, anti-inflammatory, and immunoregulatory activity, particularly in T-cells response-based diseases [54,55]. There is still no proof of whether melatonin supplementation may be useful in the complex treatment of patients with LC and with UC [56-58], as well as other diseases of digestive tract $[59,60]$, but our findings form a good background for future research in this field.

\section{Material and methods}

\subsection{Patients}

The study included 30 healthy subjects (control group C, aged $38.9 \pm 9.4$ years), 30 patients with acute phase of ulcerative colitis (group UC, aged $41.4 \pm 10.2$ years), and 30 patients with lymphocytic (group LC, aged $43.7 \pm 12.4$ years). The study was performed in the years from 2009 to 2016. The diagnosis was based on clinical, endoscopic, and histological examinations. Only patients with inflammatory changes in whole colon were included in the study. The patients with UC were classified as in the very severe stage according to Mayo Score/Disease Activity Index for Ulcerative Colitis. The patients with LC had normal endoscopic pictures, but their intraepithelial lymphocytes went over 25 per 100 epithelial cells. Moreover, the patients had intensive and chronic symptoms such as non-bloody diarrhea, abdominal pain, fecal incontinence, and others. 
Exclusion criteria: small intestinal bacterial overgrowth, food intolerance, parasitosis, exocrine pancreatic deficiency, thyroid dysfunction, metabolic and mental diseases, and chronic use of drugs, except for 5-aminosalicylates.

\subsection{Study Design and Procedures}

The following routine laboratory tests were performed in all of the subjects: blood cells count; quantification of protein, glucose, bilirubin, iron, urea, creatinine, and thyroglobulin concentration; and activity of alanine and asparagine aminotransferase, alkaline phosphatase, gamma-glutamyl transpeptidase, amylase, and lipase.

Furthermore, tests were also performed for serum concentrations of C-reactive protein (by latex agglutination photometric assay-COBAS INTEGRA 800, Indianapolis, IN, USA), fecal calprotectin (Sandwich ELISA-Quantum Blue Reader) and urine concentrations of 6-sulfatoxymelatonin (aMT6s) with enzyme immunoassay.

On the day of testing urinary aMT6s excretion, the subjects received only condensed liquid meals (Nutridrink $3 \times 400 \mathrm{~mL}$ ) with a total energy value of $1800 \mathrm{kcal}$, and $1500 \mathrm{~mL}$ noncarbonated isotonic mineral water. After completion of 24-h urine collection, the urine was centrifuged, and the samples were stored at $-70{ }^{\circ} \mathrm{C}$. The urinary aMT6s concentration was determined using Immuno Biochemical Laboratories kit (No. RE 54031). The measurements were performed by photometry at a wavelength of $450 \mathrm{~nm}$ (Expert 96-Reader-Biogenet, Józefów, Poland). The obtained results were converted from nanogram per mililiter to microgram $/ 24 \mathrm{~h}$.

Biopsy specimens were collected from the right, transverse, and left colon. The level of mRNA expression was estimated with RT-PCR, and $50 \mathrm{mg}$ of colonic tissues were used for this purpose. Briefly, colonic tissues were rapidly permeated to stabilize and protect cellular RNA with RNA stabilization reagent RNAlater ${ }^{\circledR}$ (Quiagen, Hilden, Germany). Prior to total RNA isolation, colonic tissues were homogenized with TissueRuptor (Quiagen, Hilden, Germany). Next, the total RNA was isolated using Quiagen RNeasy Plus Mini Kit (Quiagen, Hilden, Germany), according to the manufacturer's protocol. The quantity and quality of isolated RNA were estimated spectrophotometrically by Take3 plate on Synergy HT Microplate Reader (BioTek Instruments, Winooski, VT, USA). The real-time gene expression analysis was performed using the TaqMan Gene Expression Assays (Thermo Fisher Scientific, Waltham, MA, USA) with probes for TPH1, (Assay ID: Hs00188220_m1), AANAT (Assay ID: Hs01063208_g1), and ASMT (Assay ID: Hs00187839_m1), and a SensiFASTTM Probe No-ROX One-Step Kit (Bioline, Taunton, MA, USA). The HPRT (The hypoxanthine phosphoribosyltransferase, Assay ID: Hs01003267_m1) gene was a reference. Real-time PCR reaction was performed with BioRad CFX96 (BioRad, Hercules, CA, USA), according to the suggested RT-qPCR conditions. Expression analysis was performed with CFX Manager 1.6 software (BioRad, Hercules, CA, USA) using $\Delta \Delta C_{t}$ method with the HPRT gene as the reference target.

\subsection{Ethics}

The study was conducted in accordance with the Declaration of Helsinki and the principles of Good Clinical Practice. Written consent was obtained from each subject enrolled in the study, and the study protocol was approved by the Bioethics Committee of the Medical University of Lodz (RNN/242/06/KB).

\subsection{Statistical Analysis}

The non-parametric Kruskal-Wallis test was used to evaluate the expression of TPH1, AANAT and ASMT, and urinary aMT6s excretion in three groups: C, UC, and LC. The Mann-Whitney test was used for the comparison of mean values. The correlation between the value of urinary aMT6s excretion and the concentration of plasma CRP and fecal calprotectin was estimated by determination of Pearson's correlation coefficient, a linear regression equation, and the rang Spearman coefficient. The differences between the results were regarded as significant when a $p=0.05-0.001$. Statistica 9.0 
(StatSoft, Inc., Palo Alto, CA, USA) and MS Excel @007 (Microsoft Co., Redmond, WA, USA) were used for statistical analysis.

\section{Conclusions}

These results indicate that patients with ulcerative colitis and those with lymphocytic colitis may display high levels of melatonin-synthesizing enzymes in their colonic mucosa, which is possibly related to the increased melatonin synthesis as adaptive antioxidant activity. The high synthesis of melatonin in LC possibly protects colonic mucosa against macroscopic damage.

Acknowledgments: This work was supported by the grant of the Ministry of Science and Higher Education of Poland (NN-4025419/37).

Author Contributions: C.C. conceived the study, screened the patients, and carried out the clinical procedures; J.B. performed genetic procedures; J.F. carried out the biochemical analysis; J.C. participated in the study design, T.P. participated in genetic procedures and interpreted the data. All authors wrote and approved the final version of the manuscript.

Conflicts of Interest: The authors declare no conflict of interest.

\section{References}

1. Bubenik, G.A. Localization, physiological significance and possible clinical implication of gastrointestinal melatonin. Biol. Signals Recept. 2001, 10, 350-366. [CrossRef] [PubMed]

2. Reiter, R.J.; Tan, D.-X.; Mayo, J.C.; Sainz, R.M.; Leon, J.; Bandyopadhyay, D. Neurally-mediated and neurally-independent beneficial actions of melatonin in the gastrointestinal tract. J. Physiol. Pharmacol. 2003, 54 (Suppl. 4), 113-125. [PubMed]

3. Chen, C.-Q.; Fichna, J.; Bashashati, M.; Li, Y.-Y.; Storr, M. Distribution, function and physiological role of melatonin in the lower gut. World J. Gastroenterol. 2011, 17, 3888-3898. [CrossRef] [PubMed]

4. Velarde, E.; Cerdá-Reverter, J.M.; Alonso-Gómez, A.L.; Sánchez, E.; Isorna, E.; Delgado, M.J. Melatonin-synthesizing enzymes in pineal, retina, liver, and gut of the goldfish (carassius): MRNA expression pattern and regulation of daily rhythms by lighting conditions. Chronobiol. Int. 2010, 27, 1178-1201. [CrossRef] [PubMed]

5. Zagajewski, J.; Drozdowicz, D.; Brzozowska, I.; Hubalewska-Mazgaj, M.; Stelmaszynska, T.; Laidler, P.M.; Brzozowski, T. Conversion L-tryptophan to melatonin in the gastrointestinal tract: The new high performance liquid chromatography method enabling simultaneous determination of six metabolites of L-tryptophan by native fluorescence and UV-VIS detection. J. Physiol. Pharmacol. 2012, 63, 613-621. [PubMed]

6. Ceinos, R.M.; Chansard, M.; Revel, F.; Calgari, C.; Míguez, J.M.; Simonneaux, V. Analysis of adrenergic regulation of melatonin synthesis in Siberian hamster pineal emphasizes the role of HIOMT. Neurosignals 2004, 13, 308-317. [CrossRef] [PubMed]

7. Fernandes, P.A.; Tamura, E.K.; D’Argenio-Garcia, L.; Muxel, S.M.; da Silveira Cruz-Machado, S.; Marçola, M.; Carvalho-Sousa, C.E.; Cecon, E.; Ferreira, Z.S.; Markus, R.P. Dual Effect of Catecholamines and Corticosterone Crosstalk on Pineal Gland Melatonin Synthesis. Neuroendocrinology 2017, 104, 126-134. [CrossRef] [PubMed]

8. Lane, E.A.; Moss, H.B. Pharmacokinetics of Melatonin in Man: First Pass Hepatic Metabolism. J. Clin. Endocrinol. Metab. 1985, 61, 1214-1216. [CrossRef] [PubMed]

9. Facciolá, G.; Hidestrand, M.; von Bahr, C.; Tybring, G. Cytochrome P450 isoforms involved in melatonin metabolism in human liver microsomes. Eur. J. Clin. Pharmacol. 2001, 56, 881-888. [CrossRef] [PubMed]

10. Baskett, J.J.; Cockrem, J.F.; Antunovich, T.A. Sulphatoxymelatonin excretion in older people: Relationship to plasma melatonin and renal function. J. Pineal Res. 1998, 24, 58-61. [CrossRef] [PubMed]

11. Kovács, J.; Brodner, W.; Kirchlechner, V.; Arif, T.; Waldhauser, F. Measurement of urinary melatonin: A useful tool for monitoring serum melatonin after its oral administration. J. Clin. Endocrinol. Metab. 2000, 85, 666-670. [CrossRef] [PubMed]

12. Hardeland, R. Antioxidative protection by melatonin: Multiplicity of mechanisms from radical detoxification to radical avoidance. Endocrine 2005, 27, 119-130. [CrossRef] 
13. Tan, D.X.; Manchester, L.C.; Reiter, R.J.; Qi, W.B.; Karbownik, M.; Calvo, J.R. Significance of melatonin in antioxidative defense system: Reactions and products. Biol. Signals Recept. 2000, 9, 137-159. [CrossRef] [PubMed]

14. Tan, D.-X.; Manchester, L.C.; Terron, M.P.; Flores, L.J.; Reiter, R.J. One molecule, many derivatives: A never-ending interaction of melatonin with reactive oxygen and nitrogen species? J. Pineal Res. 2007, 42, 28-42. [CrossRef] [PubMed]

15. Reiter, R.J.; Mayo, J.C.; Tan, D.-X.; Sainz, R.M.; Alatorre-Jimenez, M.; Qin, L. Melatonin as an antioxidant: Under promises but over delivers. J. Pineal Res. 2016, 61, 253-278. [CrossRef] [PubMed]

16. Galano, A.; Tan, D.X.; Reiter, R.J. On the free radical scavenging activities of melatonin's metabolites, AFMK and AMK. J. Pineal Res. 2013, 54, 245-257. [CrossRef] [PubMed]

17. Rodriguez, C.; Mayo, J.C.; Sainz, R.M.; Antolín, I.; Herrera, F.; Martín, V.; Reiter, R.J. Regulation of antioxidant enzymes: A significant role for melatonin. J. Pineal Res. 2004, 36, 1-9. [CrossRef] [PubMed]

18. Silva, C.L.M.; Tamura, E.K.; Macedo, S.M.D.; Cecon, E.; Bueno-Alves, L.; Farsky, S.H.P.; Ferreira, Z.S.; Markus, R.P. Melatonin inhibits nitric oxide production by microvascular endothelial cells in vivo and in vitro. Br. J. Pharmacol. 2007, 151, 195-205. [CrossRef] [PubMed]

19. Manikonda, P.K.; Jagota, A. Melatonin administration differentially affects age-induced alterations in daily rhythms of lipid peroxidation and antioxidant enzymes in male rat liver. Biogerontology 2012, 13, 511-524. [CrossRef] [PubMed]

20. Chojnacki, J.; Śliwiński, T.; Wiśniewska-Jarosińska, M.; Turant, M.; Błasiak, J.; Kulig, A.; Majsterek, I.; Chojnacki, C. Evaluation of the number of enterochromaffin cells and melatonin metabolism exponents in subjects with ulcerative colitis. Clin. Exp. Med. Lett. 2011, 52, 19-23.

21. Neurath, M.F.; Finotto, S. The many roads to inflammatory bowel diseases. Immunity 2006, 25, $189-191$. [CrossRef] [PubMed]

22. Sartor, R.B. Mechanisms of Disease: Pathogenesis of Crohn's disease and ulcerative colitis. Nat. Clin. Pract. Gastroenterol. Hepatol. 2006, 3, 390-407. [CrossRef] [PubMed]

23. Sánchez, A.; Calpena, A.; Clares, B. Evaluating the Oxidative Stress in Inflammation: Role of Melatonin. Int. J. Mol. Sci. 2015, 16, 16981-17004. [CrossRef] [PubMed]

24. Nemeth, Z.H.; Bogdanovski, D.A.; Barratt-Stopper, P.; Paglinco, S.R.; Antonioli, L.; Rolandelli, R.H. Crohn's Disease and Ulcerative Colitis Show Unique Cytokine Profiles. Cureus 2017, 9, e1177. [CrossRef] [PubMed]

25. Chojnacki, C.; Wiśniewska-Jarosińska, M.; Kulig, G.; Majsterek, I.; Reiter, R.J.; Chojnacki, J. Evaluation of enterochromaffin cells and melatonin secretion exponents in ulcerative colitis. World J. Gastroenterol. 2013, 19, 3602-3607. [CrossRef] [PubMed]

26. El-Salhy, M.; Danielsson, A.; Stenling, R.; Grimelius, L. Colonic endocrine cells in inflammatory bowel disease. J. Intern. Med. 1997, 242, 413-419. [CrossRef] [PubMed]

27. Rybakova, M.G.; Botina, A.V.; Solov'eva, O.I. Immunomorphological characteristics of mucosal and endocrine cells of the colon in patients with chronic ulcerative colitis. Arkhiv Patol. 2005, 67, 30-33.

28. Ingle, S.B.; Adgaonkar, B.D.; Ingle, C.R.H. Microscopic colitis: Common cause of unexplained nonbloody diarrhea. World J. Gastrointest. Pathophysiol. 2014, 5, 48-53. [CrossRef] [PubMed]

29. Zabana, Y.; Ferrer, C.; Aceituno, M.; Salas, A.; Fernández-Bañares, F. Advances for improved diagnosis of microscopic colitis in patients with chronic diarrhoea. Gastroenterol. Hepatol. 2017, 40, 107-116. [CrossRef] [PubMed]

30. Fernández-Bañares, F.; Esteve, M.; Espinós, J.C.; Rosinach, M.; Forné, M.; Salas, A.; Viver, J.M. Drug Consumption and the Risk of Microscopic Colitis. Am. J. Gastroenterol. 2007, 102, 324-330. [CrossRef] [PubMed]

31. Park, T.; Cave, D.; Marshall, C. Microscopic colitis: A review of etiology, treatment and refractory disease. World J. Gastroenterol. 2015, 21, 8804-8810. [CrossRef] [PubMed]

32. Pisani, L.F.; Tontini, G.E.; Vecchi, M.; Pastorelli, L. Microscopic Colitis. Inflamm. Bowel Dis. 2016, 22, 450-458. [CrossRef] [PubMed]

33. Law, E.H.; Badowski, M.; Hung, Y.T.; Weems, K.; Sanchez, A.; Lee, T.A. Association between Proton Pump Inhibitors and Microscopic Colitis. Ann. Pharmacother. 2017, 51, 253-263. [CrossRef] [PubMed]

34. Macaigne, G.; Lahmek, P.; Locher, C.; Boivin, J.F.; Lesgourgues, B.; Yver, M.; Costes, L.; Alsamad, I.A.; Cucherousset, J.; Charpignon, C.; et al. Over $90 \%$ of cases of Microscopic Colitis can be diagnosed by performing a short colonoscopy. Clin. Res. Hepatol. Gastroenterol. 2017, 41, 333-340. [CrossRef] [PubMed] 
35. Pardi, D.S. Diagnosis and management of microscopic colitis. Am. J. Gastroenterol. 2017, 112, $78-85$. [CrossRef] [PubMed]

36. Platz-Baudin, C.; Katzenberger, T.; Eck, M. Microscopic colitis: Histopathological review with a clinicopathological correlation. Pathologe 2011, 32, 275-281. [CrossRef] [PubMed]

37. Chatelain, D.; Mokrani, N.; Fléjou, J.F. Microscopic colitis: Collagenous colitis and lymphocytic colitis. Ann. Pathol. 2007, 27, 448-458. [CrossRef]

38. El-Salhy, M.; Gundersen, D.; Hatlebakk, J.G.; Hausken, T. High densities of serotonin and peptide YY cells in the colon of patients with lymphocytic colitis. World J. Gastroenterol. 2012, 18, 6070-6075. [CrossRef] [PubMed]

39. Boznańska, P.; Wichan, P.; Stepień, A.; Wiśniewska-Jarosńska, M.; Smigielski, J.; Szadkowski, K.; Stec-Michalska, K. 24-hour urinary 6-hydroxymelatonin sulfate excretion in patients with ulcerative colitis. Pol. Merkur. Lekarski 2007, 22, 369-372. [PubMed]

40. Chen, M.; Mei, Q.; Xu, J.; Lu, C.; Fang, H.; Liu, X. Detection of melatonin and homocysteine simultaneously in ulcerative colitis. Clin. Chim. Acta 2012, 413, 30-33. [CrossRef] [PubMed]

41. Cotter, T.G.; Binder, M.; Loftus, E.V., Jr.; Abboud, R.; McNally, M.A.; Smyrk, T.C.; Tremaine, W.J.; Sandborn, W.J.; Pardi, D.S. Development of a Microscopic Colitis Disease Activity Index: A prospective cohort study. Gut 2016. [CrossRef] [PubMed]

42. Kane, J.S.; Sood, R.; Law, G.R.; Gracie, D.J.; To, N.; Gold, M.J.; Ford, A.C. Validation and modification of a diagnostic scoring system to predict microscopic colitis. Scand. J. Gastroenterol. 2016, 51, 1206-1212. [CrossRef] [PubMed]

43. Liszka, Ł.; Woszczyk, D.; Pajak, J. Histopathological diagnosis of microscopic colitis. J. Gastroenterol. Hepatol. 2006, 21, 792-997. [CrossRef] [PubMed]

44. Park, Y.S.; Kim, T.K. Is microscopic colitis really microscopic? Gut Liver 2015, 9, 137-138. [CrossRef] [PubMed]

45. Park, H.S.; Han, D.S.; Ro, Y.O.; Eun, C.S.; Yoo, K.S. Does lymphocytic colitis always present with normal endoscopic findings? Gut Liver 2015, 9, 197-201. [CrossRef] [PubMed]

46. Aust, D.E. Histopathology of microscopic colitis. Pathologe 2012, 33 (Suppl. 2), 221-224. [CrossRef] [PubMed]

47. Langner, C.; Aust, D.; Ensari, A.; Villanacci, V.; Becheanu, G.; Miehlke, S.; Geboes, K.; Münch, A. Histology of microscopic colitis-review with a practical approach for pathologists. Histopathology 2015, 66, 613-626. [CrossRef] [PubMed]

48. Pisani, L.F.; Tontini, G.E.; Marinoni, B.; Villanacci, V.; Bruni, B.; Vecchi, M.; Pastorelli, L. Biomarkers and Microscopic Colitis: An Unmet Need in Clinical Practice. Front. Med. 2017, 4, 54. [CrossRef] [PubMed]

49. El-Salhy, M.; Lomholt-Beck, B.; Gundersen, T.D. High chromogranin A cell density in the colon of patients with lymphocytic colitis. Mol. Med. Rep. 2011, 4, 603-605. [CrossRef] [PubMed]

50. El-Salhy, M.; Gundersen, D.; Hatlebakk, J.G.; Hausken, T. Chromogranin A cell density as a diagnostic marker for lymphocytic colitis. Dig. Dis. Sci. 2012, 57, 3154-3159. [CrossRef] [PubMed]

51. Spiller, R.C.; Jenkins, D.; Thornley, J.P.; Hebden, J.M.; Wright, T.; Skinner, M.; Neal, K.R. Increased rectal mucosal enteroendocrine cells, $\mathrm{T}$ lymphocytes, and increased gut permeability following acute Campylobacter enteritis and in post-dysenteric irritable bowel syndrome. Gut 2000, 47, 804-811. [CrossRef] [PubMed]

52. Dunlop, S.P.; Jenkins, D.; Neal, K.R.; Spiller, R.C. Relative importance of enterochromaffin cell hyperplasia, anxiety, and depression in postinfectious IBS. Gastroenterology 2003, 125, 1651-1659. [CrossRef] [PubMed]

53. Carrillo-Vico, A.; Calvo, J.R.; Abreu, P.; Lardone, P.J.; Garcia-Maurino, S.; Reiter, R.J.; Guerro, J.M. Evidence of melatonin synthesis by human lymphocytes and its physiological significance: Possible role as intacrine, autocrine, and/or paracrine substance. FASEB J. 2004, 18, 537-539. [CrossRef] [PubMed]

54. Lin, G.J.; Huang, S.H.; Chen, S.J.; Wang, C.H.; Chang, D.M.; Sytwu, H.K. Modulation by melatonin of the pathogenesis of inflammatory autoimmune diseases. Int. J. Mol. Sci. 2013, 14, 11742-11766. [CrossRef] [PubMed]

55. Ren, W.; Liu, G.; Chen, S.; Yin, J.; Wang, J.; Tan, B.; Wu, G.; Bazer, F.W.; Peng, Y.; Li, T.; et al. Melatonin signaling in T cells: Functions and applications. J. Pineal Res. 2017, 62. [CrossRef] [PubMed]

56. Chojnacki, C.; Wisniewska-Jarosinska, M.; Walecka-Kapica, E.; Klupinska, G.; Jaworek, J.; Chojnacki, J. Evaluation of melatonin effectiveness in the adjuvant treatment of ulcerative colitis. J. Physiol. Pharmacol. 2011, 62, 327-334. [PubMed] 
57. Jena, G.; Trivedi, P.P. A review of the use of melatonin in ulcerative colitis: Experimental evidence and new approaches. Inflamm. Bowel Dis. 2014, 20, 553-563. [CrossRef] [PubMed]

58. Esteban-Zubero, E.; López-Pingarrón, L.; Alatorre-Jiménez, M.A.; Ochoa-Moneo, P.; Buisac-Ramón, C.; Rivas-Jiménez, M.; Castán-Ruiz, S.; Antoñanzas-Lombarte, Á.; Tan, D.X.; García, J.J.; et al. Melatonin's role as a co-adjuvant treatment in colonic diseases: A review. Life Sci. 2017, 170, 72-81. [CrossRef] [PubMed]

59. Najeeb, S.; Khurshid, Z.; Zohaib, S.; Zafar, M.S. Therapeutic potential of melatonin in oral medicine and peridontology. Kaohsiung J. Med. Sci. 2016, 32, 391-396. [CrossRef] [PubMed]

60. Werbach, M.R. Melatonin for the treatment of gastroesophageal reflux disease. Altern. Ther. Health Med. 2008, 14, 534-558.

Sample Availability: Samples of the compounds are available from the authors.

(C) 2018 by the authors. Licensee MDPI, Basel, Switzerland. This article is an open access article distributed under the terms and conditions of the Creative Commons Attribution (CC BY) license (http:/ / creativecommons.org/licenses/by/4.0/). 